\title{
A NATIONAL CLEARING HOUSE AS A SAFEGUARD AGAINST PANICS
}

\author{
By J. M. Elliott,
}

President First National Bank of Los Angeles, Cal.

The panic of 1907 emphasized the closeness of even the remote parts of the country to the financial centers, and also the practical impossibility of any one banking institution's standing alone, no matter how carefully managed, in a city large enough to contain several competitors. There is a necessity of co-operation and a need of some strong bond of union among all the banks of a given locality. This may properly take the form of a clearinghouse corporation with a charter and capital, through which the financial affairs of the members and all institutions clearing through them could be regulated. It is patent to all who have observed, that a panic is but the converse of the tide of extravagance, high prices and speculation, and if these latter could be curbed or even modified, the former would not occur. If the clearing-house plan for individual cities was extended and a national clearing house formed, of which each one of the local clearing houses would be a constituent part, the trade of the country might be so regulated as to avoid the dangers which bring about these troubles, and though our advance as a people would appear slower, it would be saner and safer in every way.

These local clearing-house corporations which I am suggesting should, in addition to the usual exchange of checks and daily settlement between its members, employ a high-priced auditor, whose business would be to constantly and critically examine into the affairs of the members, and also of all banks clearing through them, and to report to the committee any infraction of good banking principles; it being the rule that any bank offending, would be first admonished, then fined, and finally expelled, if the practices were continued. Among such practices to be reprobated I may mention,pyramiding bank deposits, paying too large rates of interest, loaning too heavily to any one borrower or set of borrowers-especially directors, organizing a clique to maintain a chain of banks, the use $(460)$ 
by the officers of the money or influence of their respective banks for their personal benefit.

The national clearing house would be governed by a board elected by the members, and it should have a competent staff which would, through the reports of the local clearing houses, keep in touch with the business of the country. The order of the central association to all its members to decline to handle the checks of any bank which had been for cause expelled from a local organization, would be a penalty that few institutions would care to face. If this national clearing house should fill its mission well, it would not only inspire confidence in itself, but in all of its ramifications, and it would uplift the whole banking business of the country to a higher plane. It would in time surely attract the attention of Congress, and it would be recognized as the proper channel through which legislation would reach the banks of the country. It might in the end so modify the existing laws that no institution would be allowed to receive deposits unless it had a government charter permitting it to do so, and government examination to assist in correcting any untoward tendency. This national association could adopt rules which would keep the commercial banks, the savings banks and the trust companies closely confined to their own special lines.

The bankers of a given locality know quite well the quality of the management of their competitors, but under present conditions, those who are conducting their business in careful and honorable fashion feel compelled to keep silence while the speculative, the unfit, the unfair, and sometimes the fraudulent, competitor is following the road to ruin for himself and incidentally bringing trouble, anxiety and loss to all honestly engaged in the business, besides engendering that lack of confidence in the whole banking fabric which has been built up by the reputable by years of honest dealing. The confidence of its customers in any bank is as valuable as its capital stock, and it is unfair to allow it to be damaged by any one man or institution. If the government cannot provide protection for this valuable asset of ours which we have labored patiently for years to build up, let the bankers of the country band together in some way to protect themselves, their depositors and stockholders.

One other lesson of the financial trouble has been, I think, ap$(46 \mathrm{I})$ 
parent,-that the bank officers who were interested in many outside institutions or affairs were handicapped thereby. In other words,-the banker, to meet his obligations in the best way, should largely confine himself to his bank.

In the Far West practically the same means were taken as in the East to tide over the recent time of distress. The country banks were very much less affected than those of the cities, and in many cases conducted their business almost on normal lines. In Los Angeles, clearing-house loan certificates were issued, which have at this writing been retired. The ratio of issue was $66^{2} / 3$ to the IoO of approved securities. The scrip which was issued was merely a certificate that securities representing twice the amount of the face of each paper were held by the clearing-house committee, and its redemption was guaranteed by all the clearing-house banks. The non-clearing-house banks were allowed to avail themselves of the facilities of the clearing-house association in proportion to their needs and capital. There was some hesitation at first, principally by the laboring men, as to the acceptance of these certificates, but after a short time they passed current without any question, and their issuance had the approval of the large majority of thinking people. About ninety per cent of the total amount issued has been at this writing retired, and the ordinary circulation has very largely resumed its place. 